\title{
Floating wetland mesocosm assessment of nutrient removal to reduce ecotoxicity in stormwater ponds
}

\author{
N. B. Chang $\cdot$ M. K. Islam $\cdot$ M. P. Wanielista
}

Received: 21 July 2011/Revised: 15 October 2011/Accepted: 21 December 2011/Published online: 12 April 2012

(c) CEERS, IAU 2012

\begin{abstract}
A grouped mesocosm study was conducted with different water holding capacities and conditions to determine nutrient removal efficiency using floating wetland macrophytes. Different scenarios were created by changing water depth, littoral vegetation, sorption media and area coverage to observe how they affect nutrient removal efficiencies. Plant species were screened and selected based on the literature, local availability and previously performed microcosm studies. Sorption media were warped using geotextile filter fostering microbial colonization in the rhizospheric zone to enhance denitrification and plant growth. Water quality parameters included total nitrogen, total phosphorus, orthophosphate, nitratenitrogen and ammonia-nitrogen in addition to in situ parameters such as $\mathrm{pH}$, dissolved oxygen, temperature and chlorophyll- $a$. Composite samples across several locations were collected periodically to understand the spatial distribution or aggregation of nutrients. After 3 months of water quality monitoring, plants were analyzed for tissue nutrient concentrations, and the average uptake rate was calculated as 36.39 and $1.48 \mathrm{mg} \mathrm{m}^{-2}$ day $^{-1}$ for nitrogen and phosphorus, respectively, by the floating treatment wetland system. Finally, considering the higher nutrient aggregation in the rhizospheric zone, the removal rate with $5 \%$ area coverage and water quality improvement by littoral zone, the optimized design, placement and maintenance of the whole system were recommended.
\end{abstract}

N. B. Chang $(\square) \cdot$ M. K. Islam · M. P. Wanielista Department of Civil, Environmental, and Construction Engineering, University of Central Florida, Orlando, FL 32816, USA

e-mail: Ni-Bin.Chang@ucf.edu
Keywords Best management practice - Littoral zone · Nutrient aggregation $\cdot$ Rhizospheric zone $\cdot$ Sorption media

\section{Introduction}

Nutrients, such as ammonia, nitrite, nitrate, and phosphorus, are common contaminants in water bodies that directly or indirectly affect public health and ecosystem integrity with acute and chronic harmful outcome. For example, without proper treatment, ammonia in wastewater effluents can stimulate phytoplankton growth, exhibit toxicity to aquatic biota, and exert oxygen demand in surface waters (Beutel 2006). Undissociated ammonia is extremely volatile in aqueous solution if ammonia cannot be ionized; however, ionized ammonia is very toxic for fish species (Tarazona et al. 2008). Fish mortality, health, and reproduction can be affected by the presence of minute amounts of ammonia-N (Servizi and Gordon 2005). Nitrate can cause human health problems such as liver damage and even cancers (Gabel et al. 1982; Huang et al. 1998). Nitrate can also bind with hemoglobin and create an oxygen deficiency called methemoglobinemia in infants (KimShapiro et al. 2005). Nitrite can react with amines chemically or enzymatically to form nitrosamines that are potent carcinogens (Sawyer et al. 2003).

Stormwater runoff is highly variable in both intensity and duration due to the erratic nature of storm events. The use of constructed wetlands that use various aquatic plants to purify and remediate nutrient-rich stormwater runoff (Iamchaturapatra et al. 2007) has significantly increased (White et al. 2009; Baldwin et al. 2009; Belmont and Metcalfe 2003). The floating wetland technology is one of the best management practices (BMPs) for stormwater treatment by which macrophytes remove pollutants 
directly, providing a suitable environment for microorganisms and assimilating them into their tissue to transform pollutants and reduce their concentrations (Breen 1990; Billore et al. 2008). Sediment-rooted plants for conventional treatment of wetlands experience a range of water depths and periods of inundation (Greenway and Polson 2007). The duration of inundation, the depth of water, and the frequency of flooding or drought affect plant growth, establishment and survival. Long periods of flooding are stressful to some bottom-rooted wetland plants (Ewing 1996; Headley et al. 2006). To manage this issue, wetland area might be increased to buffer against extremes during water level fluctuations, or the high flows can be bypassed. In the latter case, a significant portion of incoming stormwater is untreated (Headley et al. 2006). In addition, the large land area required for installation is a definite limitation to their applicability. Floating treatment wetlands (FTWs) are an innovative variant of these wetland systems and a possible solution to this problem.

Plants grow on floating mats rather than rooted in the sediments (Fig. 1); therefore, water depth is not a concern, and the mats are unlikely affected by fluctuations in water levels.

Biologically, an aquatic macrophyte-based wastewater treatment system is far more diverse than present-day mechanical treatment systems (Hammer 1989; Moshiri 1993). Free-floating macrophytes shade the water column, resulting in a cooler habitat for fish and macroinvertebrates (Nahlik and Mitsch 2006). The hanging roots provide a large surface area for denitrifying bacteria, creating an anaerobic environment that can remove nitrate by the denitrification process (Govindarajan 2008), and entrap fine suspended particulates that would otherwise remain in suspension in a conventional pond system (Headley et al. 2006). Microbes that live on the surface of plant roots in a wetland remove 10 times more nitrate than do the plants themselves (Adams 1992). These microbes change nitratenitrogen $\left(\mathrm{NO}_{3}-\mathrm{N}\right)$ to ammonia-nitrogen $\left(\mathrm{NH}_{4}-\mathrm{N}\right)$ in a process called dissimilatory nitrate reduction to ammonium (DNRA). As the plants in floating wetlands are not rooted in sediments, they are forced to acquire nutrition directly from the water column (Headley et al. 2006; Vymazal 2007). The rate of nutrient and other element uptake into biomass increases as physiological growth continues. Total nitrogen (TN) and total phosphorus (TP) can be removed if the plants are harvested regularly. Finally, algal toxin growth is prevented due to lack of nutrients.

Various species are found to be suitable for floating wetlands. Pioneer floating mat-forming species include Typha latifolia, T. angustifolia, Phragmites australis, Panicum hemitomon, Glyceria maxima, Carex lasiocarpa, Menyanthes trifoliata, Myrica gale, and Chamaedaphne calyculata (Headley et al. 2006). Water hyacinths (Eicchornea crassipes) and duckweed species (Lemna, Spirodela, and Wolfiella) are also regarded as typical plant species for floating wetland used in large-scale applications (Kadlec and Knight 1996; DeBusk et al. 1995). These candidate plants along with others are being used by local nurseries to promote floating islands. T. japonica, $E$. crassipes, and $P$. stratiotes performed high nutrient removal efficiencies when nutrient removal rates were calculated by the biomass-based method, but they were not efficient when nutrient removal rates were calculated by the area-based method (White et al. 2009). Both Canna flaccida and Juncus effussus are indigenous to the wetlands of Florida and have proven effective at taking up nutrients (White et al. 2009; Cui et al. 2010). Agrostis alba is also effective but not native in Florida.

To date, little information has been published in regard to the planning, design, and operation of FTWs. To further the advancements of FTW technologies, the addition of sorption media to increase water holding capacity is
Fig. 1 Floating treatment wetland on a typical wet detention pond

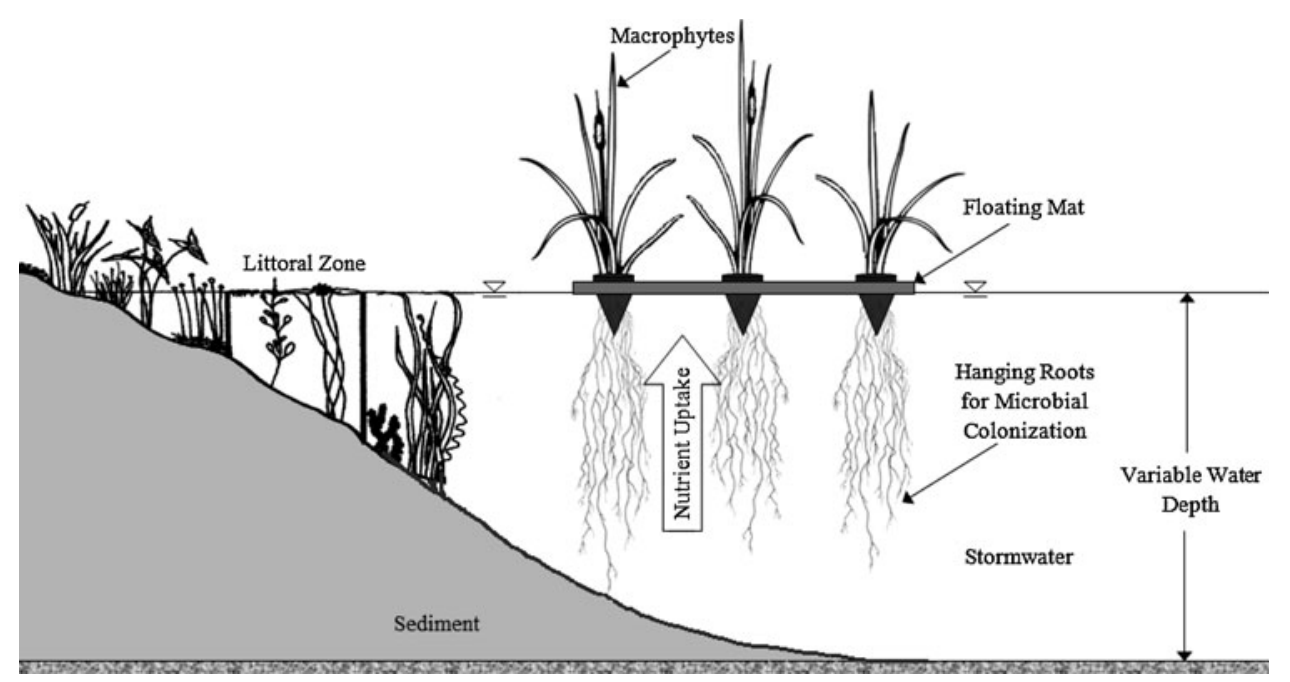


expected to significantly improve nutrient removal (Chang et al. 2007) and production of plant biomass (Figge et al. 1995). Sorption media also improve tissue culture responses, including somatic embryogenesis, organogenesis, adventitious shoot production and growth, and the rooting of micro-propagated tissues (Van Winkle and Pullman 2005). As there is no soil in the rhizospheric zone of FTWs, the incorporation of sorption media promotes a sorption surface between the pollutant and the sorption medium, causing the pollutants to leave the aqueous solution and adhere to the sorption medium (Hossain et al. 2010). Thus, phosphorus is removed by both adsorption and absorption. Moreover, a biofilm can form on the surface of media particles that allows microbes to assimilate nitrogen species, although nitrogen cannot be removed by sorption directly. It is indicative that sorption provides an environment for subsequent nitrification and denitrification (Xuan 2007). These sorption media remove not only nutrients but also pollutants such as heavy metals, pathogens, pesticides, and toxins (Chang et al. 2010).

This paper presents a series of mesocosm experiments designed to better understand the capabilities of FTWs in terms of nutrient removal efficiencies and elucidate the contribution of littoral zone emergent plants and bottom sediments. In addition, water depth, percent area coverage, and the addition of sorption media were varied to determine the optimum design components for the system. Finally, ANOVA statistical analysis was applied to show mathematically how salient these impacts would be in each mesocosm setup relative to others. The experiment took place in Florida during winter season (November 2010 to February 2011). Our study hypotheses were: (1) variation of water depth examined in this work would not affect the nutrient removal efficiency of the floating macrophytes; (2) area coverage of floating mat would have a significant impact on nutrient removal efficiency; (3) existence of a littoral zone should improve the water quality in terms of reducing turbidity, chlorophyll- $a$ (Chl- $a$ ), and other pollutants, and might change the nutrient removal efficiencies by acting either as a sink for pollutants or by removing them; (4) sorption media should enhance nutrient removal efficiency by both adsorption and absorption processes; (5) an aggregation of nutrients near the rhizospheric zone should result in a higher concentration beneath the floating mat.

\section{Materials and methods}

\section{Selection of plant species}

Based on previous research and adaptability to the weather of Florida, Canna and Juncus were selected as the floating macrophytes for the mesocosm study; Bulrush (Scirpus californicus) and Pickerelweed (Pontederia cordata) were selected as littoral flora because they are endemic to Florida and are suitable for the allowable maximum water depth for littoral planting according to the mesocosm experimental design under study.

\section{Selection of sorption media}

Engineered, functionalized, and natural sorption media can be used to treat stormwater, wastewater, groundwater, landfill leachate, and sources of drinking water for nutrient removal via physicochemical and microbiological processes (Chang et al. 2010). The media may include but are not limited to sawdust, peat, compost, zeolite, wheat straw, newspaper, sand, limestone, expanded clay, wood chips, wood fibers, mulch, glass, ash, pumice, bentonite, tire crumb, expanded shale, oyster shell, and soy meal hull (Hossain et al. 2010).

A unique recipe of sorption medium [Bold and Gold Stormwater $\left.^{\mathrm{TM}}(\mathrm{B} \& \mathrm{G})\right]$ was applied to support the current floating wetland study. This medium is effective in reducing nitrogen (up to $47 \%$ ) and phosphorus (up to $87 \%$ ) from stormwater found in wet detention ponds (B\&G: Filtration Media, 2011). It does not easily become exhausted or saturated and thus can be used without frequent replacement. $B \& G$ medium is a tire-crumb-based composition with varying mixtures for different applications. Based on a previously performed microcosm study, $80 \%$ expanded clay was mixed with $20 \%$ tire-crumb.

\section{Experimental design}

Eleven scenarios were created with varying percent area coverage, littoral zone, and water depth (Fig. 2; Table 1). Case- 1 and case- 2 were set up as controls without floating macrophytes. Sorption media were used in all cases except case-7b, which was a no sorption media control case. Considering feasibility in an actual pond, percent area coverage was limited to $10 \%$. Two different water depths were chosen, 90 and $56 \mathrm{~cm}$, which had bottom sediment thicknesses of 50 and $30 \mathrm{~cm}$, respectively. A slope of 1:5 was maintained toward the center of the cylindrical mesocosms for the bottom sediment layer.

\section{Experimental setup}

Cylindrical plastic tanks, $5 \mathrm{~m}$ diameter $\times 1.2 \mathrm{~m}$ depth and $3 \mathrm{~m}$ diameter $\times 0.8 \mathrm{~m}$ depth with a water holding capacity of 18,000 and 4,000 L, respectively, were used as mesocosms. Sediment was collected from an actual pond bottom before flooding and placed under all mesocosms for planting emergent littoral zone plants. Even where there 
Fig. 2 A schematic diagram of the mesocosm setup

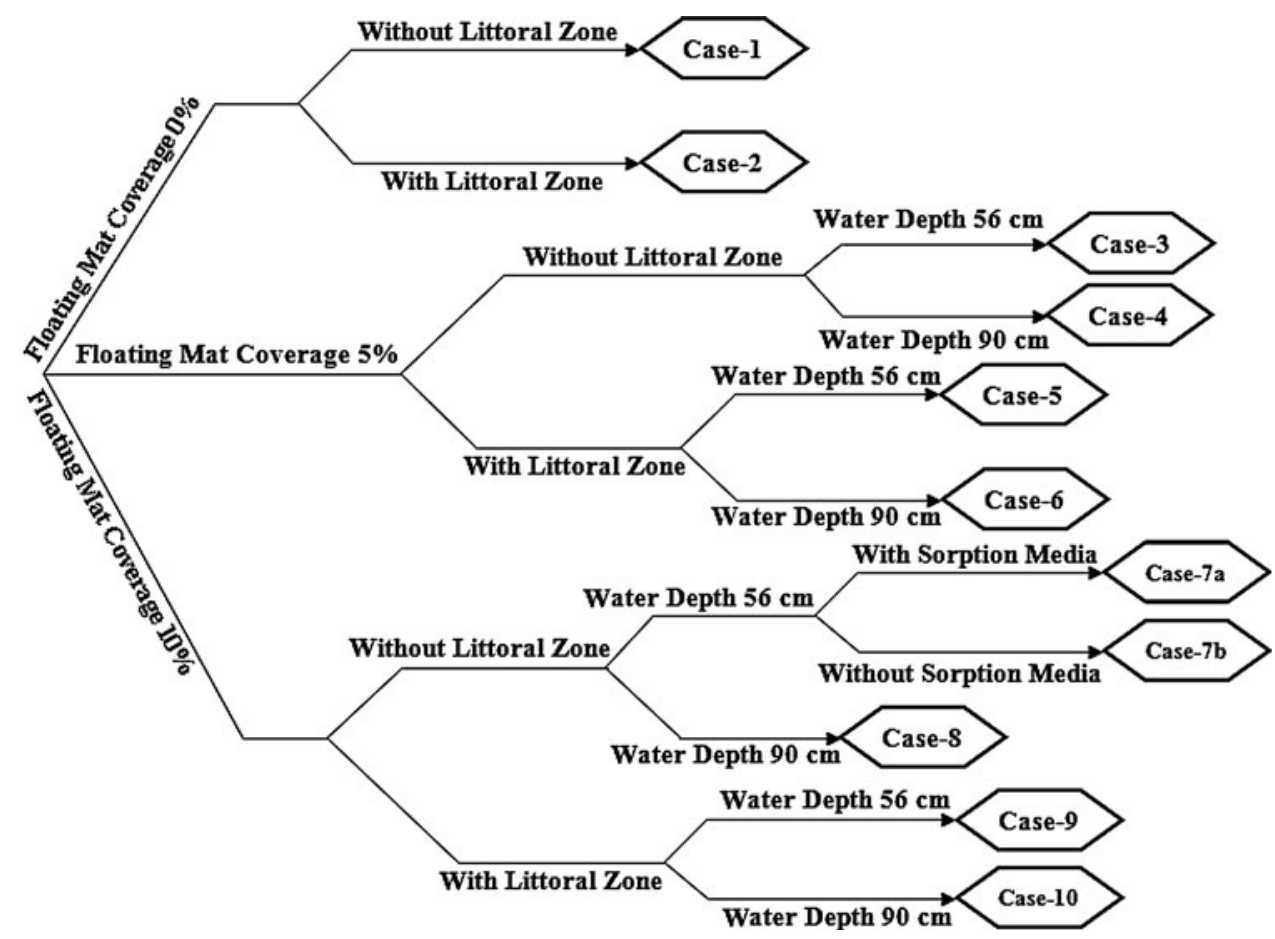

Table 1 Groupwise effluent concentration after 30 days (Cycle-1)

\begin{tabular}{|c|c|c|c|c|c|c|c|c|}
\hline \multirow[t]{2}{*}{ Scenario } & \multicolumn{2}{|c|}{ Total phosphorus } & \multicolumn{2}{|c|}{ Orthophosphate } & \multicolumn{2}{|c|}{ Total nitrogen } & \multicolumn{2}{|c|}{ Nitrate-nitrogen } \\
\hline & $\begin{array}{l}\text { Influent } \\
\left(\mathrm{mg} \mathrm{L}^{-1}\right)\end{array}$ & $\begin{array}{l}\text { Effluent } \\
\left(\mathrm{mg} \mathrm{L}^{-1}\right)\end{array}$ & $\begin{array}{l}\text { Influent } \\
\left(\mathrm{mg} \mathrm{L}^{-1}\right)\end{array}$ & $\begin{array}{l}\text { Effluent } \\
\left(\mathrm{mg} \mathrm{L}^{-1}\right)\end{array}$ & $\begin{array}{l}\text { Influent } \\
\left(\mathrm{mg} \mathrm{L}^{-1}\right)\end{array}$ & $\begin{array}{l}\text { Effluent } \\
\left(\mathrm{mg} \mathrm{L}^{-1}\right)\end{array}$ & $\begin{array}{l}\text { Influent } \\
\left(\mathrm{mg} \mathrm{L}^{-1}\right)\end{array}$ & $\begin{array}{l}\text { Effluent } \\
\left(\mathrm{mg} \mathrm{L}^{-1}\right)\end{array}$ \\
\hline Case-1 & 1.523 & 0.556 & 1.183 & 0.061 & 4.161 & 1.251 & 0.778 & 0.072 \\
\hline Case-2 & 2.858 & 1.476 & 2.560 & 1.386 & 4.300 & 0.768 & 0.896 & 0.099 \\
\hline Case-3 & 3.156 & 0.589 & 2.215 & 0.345 & 5.567 & 0.768 & 0.942 & 0.072 \\
\hline Case-4 & 2.189 & 0.909 & 1.379 & 0.063 & 3.885 & 2.072 & 1.119 & 0.099 \\
\hline Case-5 & 3.649 & 0.909 & 2.413 & 0.336 & 3.724 & 1.348 & 0.642 & 0.072 \\
\hline Case-6 & 3.361 & 0.692 & 2.086 & 0.559 & 3.217 & 0.092 & 0.815 & 0.079 \\
\hline Case-7a & 2.313 & 0.742 & 2.001 & 0.462 & 3.447 & 1.348 & 0.916 & 0.065 \\
\hline Case-7b & 2.807 & 0.398 & 2.253 & 0.210 & 4.253 & 0.816 & 1.030 & 0.057 \\
\hline Case- 8 & 2.846 & 0.692 & 2.528 & 0.728 & 3.516 & 0.913 & 0.522 & 0.079 \\
\hline Case-9 & 3.034 & 0.409 & 2.403 & 0.338 & 2.594 & 0.961 & 0.754 & 0.072 \\
\hline Case-10 & 2.327 & 0.809 & 2.270 & 0.781 & 4.000 & 1.106 & 1.312 & 0.099 \\
\hline
\end{tabular}

was no littoral zone, sediment was placed at the bottom to mimic an actual pond environment. Mesocosms were placed in an open field to ensure proper light, natural temperature, wind mixing, atmospheric gas exchange, and convective currents in the water column. Natural wind, rainfall events, and evaporation ensured that aeration imitated conditions in an actual pond.

Buoyant, interlocked puzzle-cut foam mats $(60 \times$ $60 \mathrm{~cm}$ ) used to keep the plants floating were joined by nylon connectors so that they could be assembled in any size or shape. After the mats were connected, plants were inserted into pre-cut holes in perforated plastic pots.
Sorption media were added in an innovative way so that they can float along with the plants. Mirafi ${ }^{\circledR}$ N-Series Nonwoven Polypropylene Geotextile was wrapped around the perforated pots to contain the sorption media inside. Including the plant, each pot held about $60 \mathrm{~g}$ of media. For the control case with no sorption media, inert coconut fiber was used to hold the plants upright.

Water was collected from an actual stormwater pond on the University of Central Florida campus, and the background study of the pond showed a low nutrient concentration $\left(0.40 \mathrm{mg} \mathrm{L}^{-1} \mathrm{TN}\right.$ and $\left.0.008 \mathrm{mg} \mathrm{LTP}^{-1}\right)$. Therefore, nutrients ( $3 \mathrm{mg} \mathrm{L}^{-1}$ nitrate and $1 \mathrm{mg} \mathrm{L}^{-1}$ phosphate) were 
dosed to determine nutrient removal efficiency. Commonly used fertilizers potassium nitrate $\left(\mathrm{KNO}_{3}\right)$ and monopotassium phosphate $\left(\mathrm{KH}_{2} \mathrm{PO}_{4}\right)$ were used in this case. Dosing and addition of new stormwater were performed once every 30 days to imitate natural rainfall events and consequent nutrient-rich surface runoff. Samples were collected on a biweekly basis for 3 months (November-February), and removal efficiency was calculated using the formula: $\%$ Removal $=[$ (initial concentration - final concentration $) /$ initial concentration] $\times 100 \%$. Samples collected from five different points (Fig. 3) were mixed together to achieve a composite sample deemed representative of the whole mesocosm. Each sample was collected at 11:00 am from a 6 inch depth beneath the water level.

\section{Chemical analysis}

A DR 2800 Spectrophotometer was used to analyze nutrient concentrations. The methods used in chemical analyses include Hach sensION156 (Product \#: 5465014)

Fig. 3 Contour diagram of nutrient concentrations
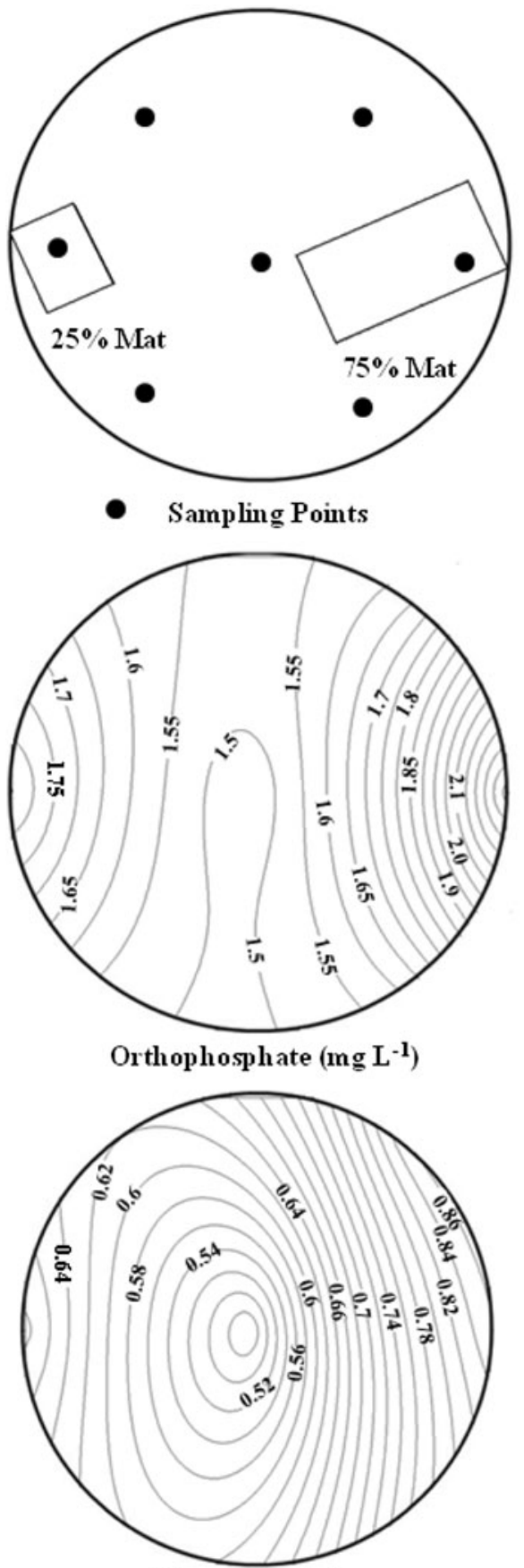

Nitrate $\left(\mathbf{m g ~ L}{ }^{-1}\right)$

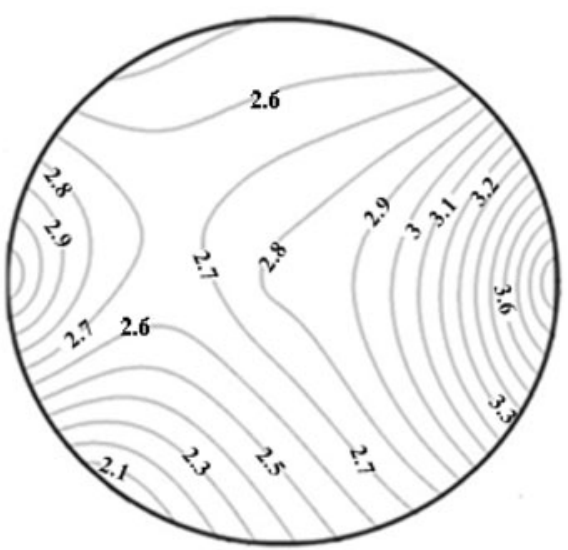

Total Phosphorus (mg L $\left.{ }^{-1}\right)$
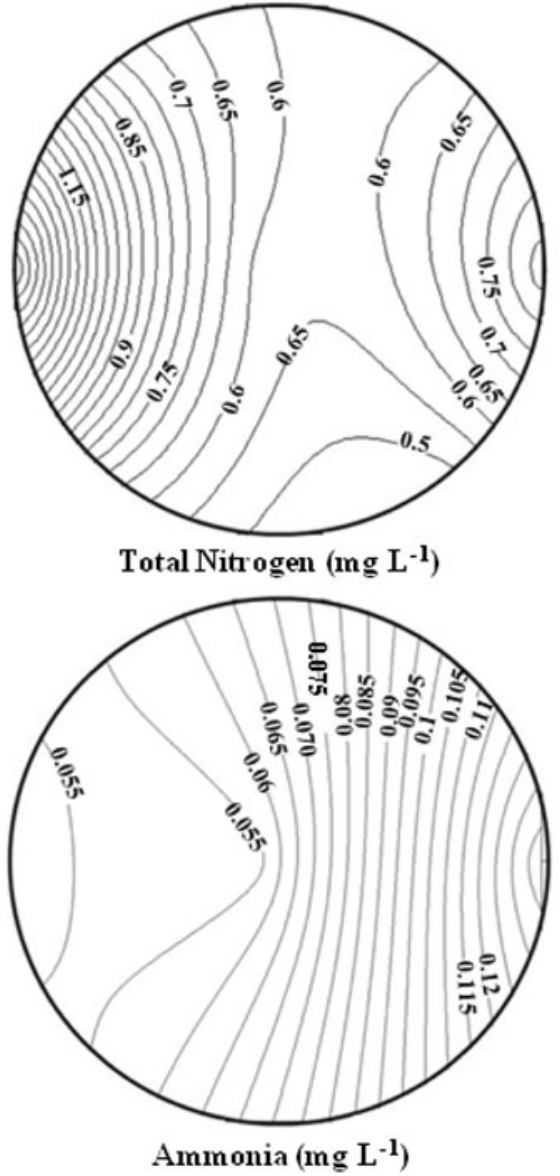

Springer 
for pH, Hach sensION156 (Product \#: 5465014) for conductivity, Hach sensION156 (Product \#: 5465014) for dissolved oxygen (DO), turbidimeter for turbidity, Aquafluor ${ }^{\mathrm{TM}}$ Handheld Fluorometer for Chl- $a$, persulfate digestion method (Hach Method 10071) for TN, salicylate method (Hach Method 8155) for ammonium, cadmium reduction method (Hach Method 8192, 8171) for nitrate, acid persulfate digestion method (Hach Method 8190) for TP, and PhosVer 3 (ascorbic acid) method (Hach Method 8048) for orthophosphate (OP). To maintain quality assurance/quality control (QA/QC) protocol, duplicate samples were analyzed every 10 samples. Preservation was done with acidification when necessary, and percent recovery was ensured within $80-120 \%$ each time. All water sampling equipment was acid-rinsed followed by flushing in distilled water prior to sampling of each tank.

\section{Results and discussion}

According to The National Stormwater Quality Database (NSQD) (Pitt et al. 2004), stormwater runoff contains on average $3 \mathrm{mg} \mathrm{L}^{-1} \mathrm{TN}$ and $<1 \mathrm{mg} \mathrm{L}^{-1} \mathrm{TP}$. Due to variations in bottom mud compaction and corresponding changes in water volume, it was difficult to maintain constant initial nutrient loading in our experiment; therefore, a small amount of deviation from the usual stormwater quality was observed in the initial nutrient concentrations. Both influent and effluent concentrations of various parameters (Table 1) indicate the efficacy of the FTW system. Although the control case (case-1) is supposed to show little nutrient removal, growth of undesirable plant species like duckweed (Lemna minor) and algae hampered our comparison. In other cases, effluent concentrations were satisfactorily low. Actually, the absence of initial plantings in the control case allowed volunteer algal species or plants to grow and cover the whole surface, resulting in significant nutrient removal. Duckweeds require ample nutrients to grow, so typically they are found in nutrient-rich environments. A surface layer of duckweeds will prevent sunlight from reaching the deeper parts of the water column, suppressing photosynthesis and oxygen production by underwater plants and algae, which can greatly stress or even kill fishes.

Nutrients aggregation toward Rhizospheric zone

Sasser et al. (1991) reported that nitrogen and phosphorus concentrations within the floating marsh system were consistently higher than adjacent lake and sediment-rooted swamp water, possibly because the plant root mats have a much greater potential for interaction with the water column. There is a high likelihood that any dissolved elements liberated from decomposing root or peat material suspended in the floating mat will return to the underlying water column. The dissolved nutrients that are enriched in the free-water under the floating mat are drawn upward by the transpiration stream, and root absorption and microbial activity decrease their concentrations in the upper levels of the marsh substrate. To observe nutrient aggregation, case8 was selected because it has $90 \mathrm{~cm}$ water depth, no littoral zone, and $10 \%$ coverage of floating mat.

To observe this phenomenon, floating mats were split (75 and $25 \%$ ) and anchored in two opposite edges of the mesocosm. Samples were collected from both edges, directly beneath the floating mats and far from the root zone. At the beginning of the study, nutrient concentration was homogenous across the surface area irrespective of the vicinity of the root zone. After 30 days, samples were again collected in the same manner and tested in the laboratory. Observed values were plotted (Fig. 3) in the contouring software Surfer 8.0 and showed that nutrient concentration was much higher near the root zone, and in all cases (except $\mathrm{TN}$ ), density was higher near the larger floating mat.

\section{Variation of physical parameters}

Temperature and $\mathrm{pH}$ did not change significantly during 3 months of observation (Fig. 4). DO was lowest (8.04 $\mathrm{mg} \mathrm{L}^{-1}$ ) in the control case due to the lack of FTWs. However, average DO was high, $9.48 \mathrm{mg} \mathrm{L}^{-1}$, in all mesocosms due to sufficient natural aeration and the absence of fish or other macroinvertebrates. In case-4, Chl- $a$ was observed to be much higher $\left(6.88 \mu \mathrm{g} \mathrm{L}^{-1}\right)$ than in other cases. Some sort of contamination might have occurred in this mesocosm. A decrease in turbidity (Table 2) with increasing use in FTWs was also observed. For example, the control case (case-1) with no FTWs showed the highest turbidity (26.69 NTU); case-2 with a littoral zone was more transparent (18.56 NTU), and case10 with both a littoral zone and $10 \%$ mat coverage was the most transparent. This result is reasonable because both sediment-rooted and floating plants reduce the amount of sediments that accumulates within the system by retaining biosolids within the root mass.

\section{Effect of water depths}

Several mesocosms were set up with varying depth of water column under the floating mats. One-way ANOVA test was performed by Minitab software to check if there was a significant impact of water depth on the removal efficiency. Although removal efficiency increased with larger water column depth for TN and nitrate, TP, and OP decreased. ANOVA test $p$ values (TN 0.459, TP 0.114, 
Fig. 4 Variation of $\mathrm{pH}$, DO, Chl- $a$, and temperature

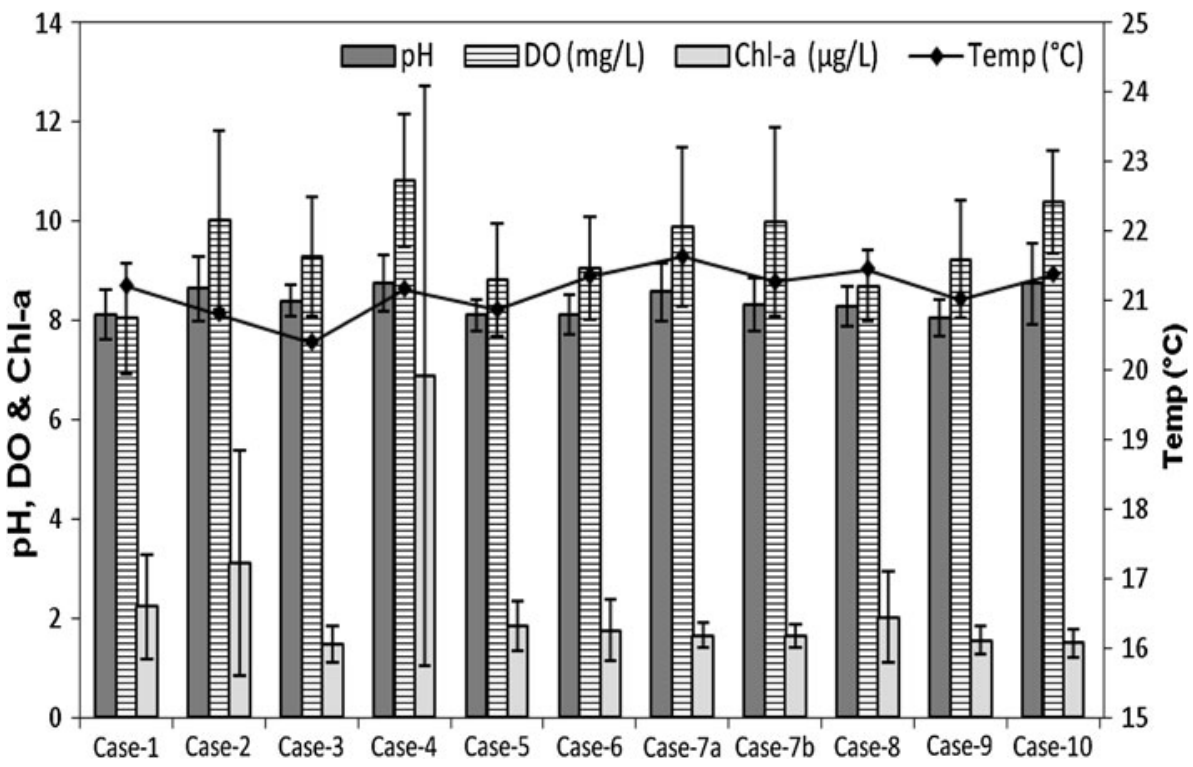

Table 2 Average turbidity decrease with increasing vegetation (sample size: $25 \mathrm{~mL}$ )

\begin{tabular}{lc}
\hline Scenario & $\begin{array}{l}\text { Average } \\
\text { turbidity (NTU) }\end{array}$ \\
\hline Case-1 & $26.69 \pm 19.22$ \\
Case-2 & $18.56 \pm 20.55$ \\
Case-3 & $8.38 \pm 3.81$ \\
Case-4 & $22.36 \pm 28.20$ \\
Case-5 & $24.09 \pm 21.26$ \\
Case-6 & $10.15 \pm 9.48$ \\
Case-7a & $17.05 \pm 13.37$ \\
Case-7b & $16.41 \pm 19.62$ \\
Case-8 & $9.85 \pm 9.24$ \\
Case-9 & $7.45 \pm 4.47$ \\
Case-10 & $7.44 \pm 10.70$ \\
\hline
\end{tabular}

nitrate 0.464 , and OP 0.377) indicate that water column depth is not statistically significant across the relevant mesocosms. From these observations, it can be concluded that varying water depth is not a concern in terms of treatment efficiency of nutrient removal in FTW systems, which might be affected by fluctuations in seasonal water levels. For this reason, it is predicted that even during excessive rainfall, the FTW systems will continue to work, although the sediment-rooted plants might be inactive.

\section{Effect of area coverage percentage}

Excluding the control case, nutrient removal efficiency was not significantly different (Fig. 5a) between mesocosms with 5 and $10 \%$ floating macrophyte coverage. It can be inferred that, even without the presence of a littoral zone, $5 \%$ coverage is sufficient to significantly remove nutrients
$(53.82 \% \mathrm{TP}, 48.06 \%$ OP, $31.84 \% \mathrm{TN}$, and $48.21 \%$ nitrate) in only 15 days. Moreover, in an actual pond with a large surface area requirement, a floating mat coverage $>5 \%$ might not be feasible because it would also inhibit sunlight from reaching the bottom of the pond. Chl- $a$ decreased gradually with the increase of percent area coverage (Fig. 5), which indicates a decrease in algae. Algae cannot compete for nutrients with floating plants; however, without a littoral zone, this relationship is not salient (Fig. 5b).

\section{Effect of littoral zone}

Wetland littoral zones involve interaction among aquatic plants, microorganisms, and physical-chemical processes such as adsorption, precipitation, and sedimentation (Gersberg et al. 1986). These zones may act as either sinks for pollutants, removing them from incoming water, or as sources, adding them to the water (Mickle and Wetzel 1978a, b; van der Valk et al. 1979; Carpenter and Lodge 1986). A comparison of case- 3 and 5 shows that the effect of the littoral zone is prominent on Chl- $a$ and turbidity (Fig. 6), both of which decreased significantly due to the presence of littoral zone. However, nutrient removal efficiency was similar in both cases. Comparison of other specific cases also shows the effect of the littoral zone, but because nutrient removal is not affected, deciding which experimental setup is best in terms of nutrient removal efficiency in these experiments is not possible.

\section{Effect of sorption media}

TP and OP removal was much higher (Table 3) in the mesocosm with sorption media, especially in cycle- 2 and 3 . 
Fig. 5 a Effect of \% area coverage with littoral zone (15 days removal efficiency), b effect of $\%$ area coverage without littoral zone (15 days removal efficiency) (a)

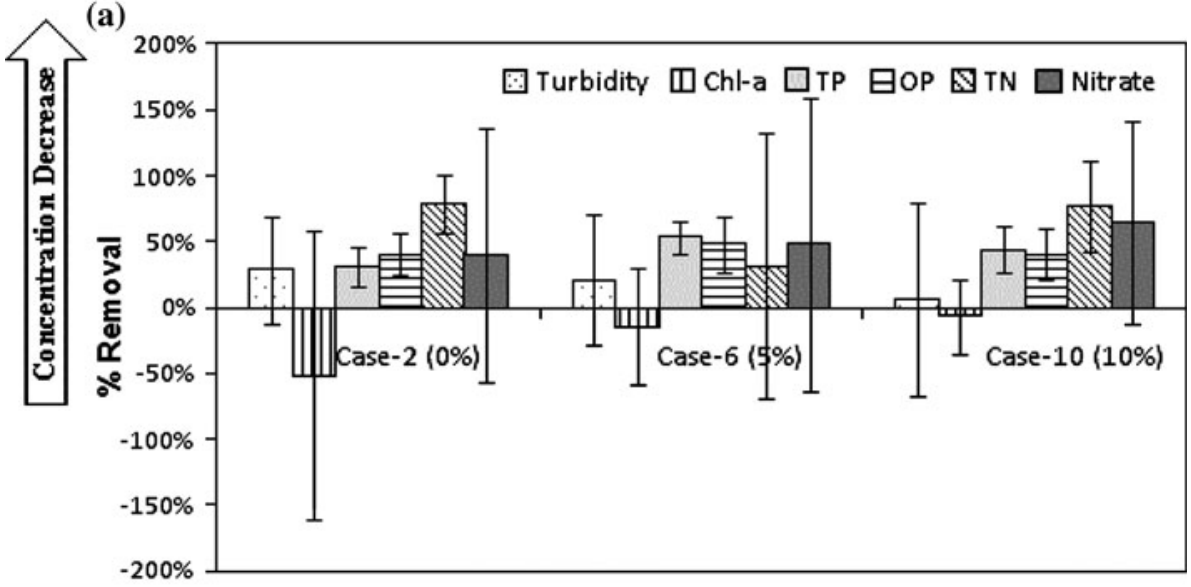

(b)

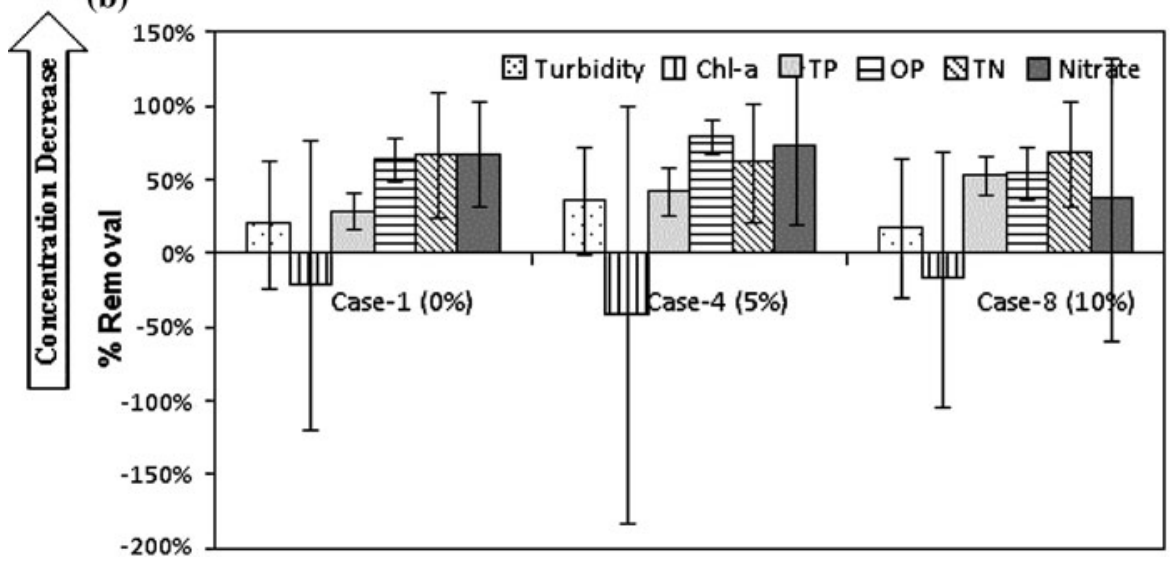

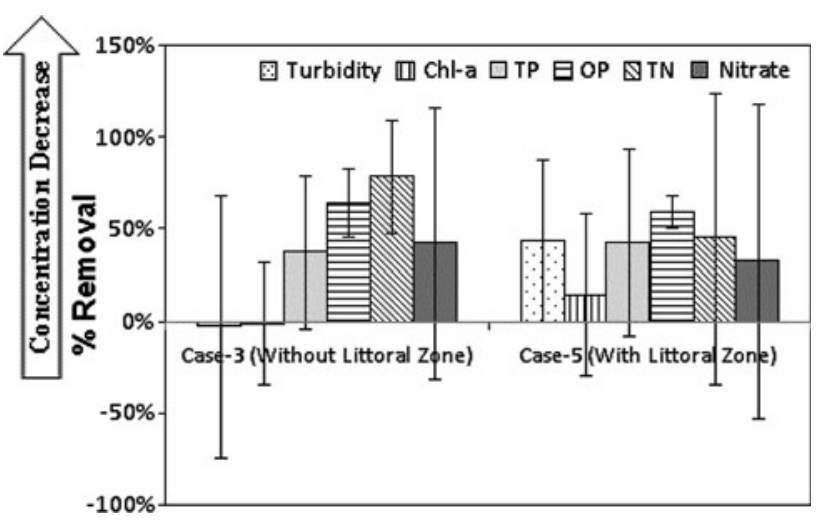

Fig. 6 Effect of littoral zone on removal efficiencies (15 days removal efficiency)

Nitrate removal efficiency was almost same. However, TN removal was higher in the mesocosm without any media. Phosphorus might be removed by both adsorption and absorption. Moreover, a biofilm formation is possible on the surface of the sorption media particles that allows microbes to assimilate nitrogen species, although nitrogen cannot be removed by sorption directly.
Tissue nutrient concentrations

After 3 months of observation on water quality, representative plant samples (floating macrophyte) from each mesocosm were analyzed to determine their tissue nutrient concentrations in the roots and shoots. Results are expressed (Fig. 7) as the percentage of their dry weights. Roots and shoots took up almost equal amounts of nutrients. Nitrogen uptake was much higher than that of phosphorus, which is commensurate with the amount of dosing. Considering plant species, Canna was better than Juncus in both shoots and roots. Assuming all the plants in a mesocosm have taken the same amount of nutrient as the representative sample, daily nutrient uptake per unit area of floating mat was calculated for nitrogen and phosphorus in each mesocosm; on average, nitrogen uptake rate was $36.39 \mathrm{mg} \mathrm{m}^{-2}$ day $^{-1}$ and phosphorus uptake rate was $1.48 \mathrm{mg} \mathrm{m}^{-2}$ day $^{-1}$ for the FWT systems.

Final remarks

Based on short-term uptake measurements in wetland and aquatic systems, however, the findings may not be all- 
Table 3 Effect of sorption media on effluent water quality

\begin{tabular}{|c|c|c|c|c|c|c|c|c|c|}
\hline \multirow[t]{2}{*}{$\mathrm{Cycle}^{\mathrm{a}}$} & \multirow[t]{2}{*}{ Sorption media } & \multicolumn{2}{|c|}{ Total phosphorus } & \multicolumn{2}{|c|}{ Orthophosphate } & \multicolumn{2}{|c|}{ Total nitrogen } & \multicolumn{2}{|c|}{ Nitrate-nitrogen } \\
\hline & & $\begin{array}{l}\text { Influent } \\
\left(\mathrm{mg} \mathrm{L}^{-1}\right)\end{array}$ & $\begin{array}{l}\text { Effluent } \\
\left(\mathrm{mg} \mathrm{L}^{-1}\right)\end{array}$ & $\begin{array}{l}\text { Influent } \\
\left(\mathrm{mg} \mathrm{L}^{-1}\right)\end{array}$ & $\begin{array}{l}\text { Effluent } \\
\left(\mathrm{mg} \mathrm{L}^{-1}\right)\end{array}$ & $\begin{array}{l}\text { Influent } \\
\left(\mathrm{mg} \mathrm{L}^{-1}\right)\end{array}$ & $\begin{array}{l}\text { Effluent } \\
\left(\mathrm{mg} \mathrm{L}^{-1}\right)\end{array}$ & $\begin{array}{l}\text { Influent } \\
\left(\mathrm{mg} \mathrm{L}^{-1}\right)\end{array}$ & $\begin{array}{l}\text { Effluent } \\
\left(\mathrm{mg} \mathrm{L}^{-1}\right)\end{array}$ \\
\hline \multirow[t]{2}{*}{ Cycle-1 } & With media & 2.313 & 0.742 & 2.001 & 0.462 & 3.447 & 1.348 & 0.916 & 0.065 \\
\hline & Without media & 2.807 & 0.398 & 2.253 & 0.210 & 4.253 & 0.816 & 1.030 & 0.057 \\
\hline \multirow[t]{2}{*}{ Cycle-2 } & With media & 1.668 & 0.264 & 0.767 & 0.137 & 1.969 & 0.000 & 0.661 & 0.133 \\
\hline & Without media & 1.841 & 0.664 & 0.844 & 0.214 & 1.244 & 0.000 & 0.840 & 0.010 \\
\hline \multirow[t]{2}{*}{ Cycle-3 } & With media & 3.538 & 0.883 & 1.948 & 0.385 & 0.744 & 0.512 & 0.231 & 0.114 \\
\hline & Without media & 3.816 & 1.832 & 2.329 & 1.190 & 1.384 & 0.000 & 0.307 & 0.086 \\
\hline
\end{tabular}

a 30 day monthly cycle

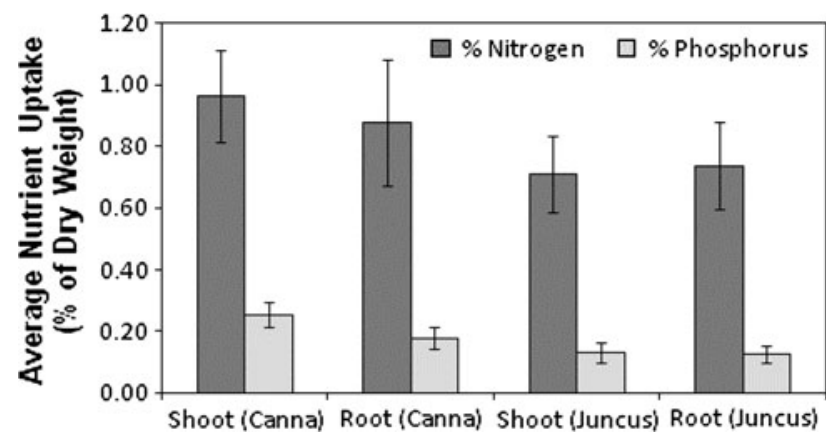

Fig. 7 Average tissue nutrient concentrations ( $\%$ of dry weight)

inclusive. Although mesocosms were not replicated, identical cycles were performed to ensure that aforementioned removal efficiencies were consistent. At least, this study shows that even in the mesocosm study of FTWs, it is important to include a littoral zone and bottom sediments because they can regulate the metabolism of the entire ecosystem in the pond. Nevertheless, additional studies are needed with typical wetland hydrologic characteristics with different types of vegetation or floating mats to better understand the effects on overall epiphyte, phytoplankton, and macrophyte ecology to elucidate the internal nutrient dynamics.

\section{Conclusion}

Implementing FTWs on existing stormwater wet detention pond systems should be an effective way to increase nutrient treatment performances without structural changes to a pond. From this mesocosm study, it can be concluded that varying water depth is not a concern in terms of treatment efficiency of nutrient removal in FTWs, which might be affected by fluctuations in seasonal water levels. For this reason, it is predicted that even during excessive rainfall, the FTW systems will continue to work, although the sediment-rooted plants might be inactive. Within the feasible limit of floating mat coverage, an increase from 5 to $10 \%$ did not significantly increase system efficiency. A
$5 \%$ coverage of floating mats can achieve $53 \%$ TP, $79 \%$ OP, $61 \%$ TN, $73 \%$ nitrate, and almost $100 \%$ ammonia removal within 15 days time span when the initial concentration is approximately $1 \mathrm{mg} \mathrm{L}^{-1}$ phosphate and $3 \mathrm{mg} \mathrm{L}^{-1}$ nitrate. More area coverage is not suitable from engineering perspective and might inhibit sunlight from reaching the bottom of an actual pond. Existence of a littoral zone increased transparency of water column by reducing turbidity and Chl- $a$. However, in our experiment, it was not clearly understood whether littoral plants helped remove pollutants, acted as a source, or simply played the role of a neutral site for attachment. TP and orthophosphate had higher removal rates in the mesocosm with sorption media, whereas, nitrate removal was almost the same and TN removal was not significant with the addition of sorption media. Spatial sampling and contour diagrams show that a higher concentration of nutrients was observed near the rhizospheric zone; therefore, it is recommended that the deployment of the FTWs should not be in the vicinity of the outlet of the pond, because the assimilated nutrients around the root zone might break loose and contaminate the discharged water through the outlet. FTWs clearly can significantly suppress algae and duckweed growth, which may harm fish populations and create aesthetic issues in stormwater management wet detention ponds. Ease of harvesting is another advantage of this FTW system, which is important because the full vegetation cycle involves return of most nutrients from senescing and decomposing.

Acknowledgments The authors are grateful for the financial support of this project provided by the Florida Department of Transportation (FDOT) (Grant No. bdk7898501). The authors wish to thank Beeman's Nursery for providing floating mats and plants. Assistance with experimental setup by Erik Stuart is also gratefully acknowledged.

\section{References}

Adams EB (1992) Wetlands: nature's water purifiers. Cooperative Extension. Washington State University, Pullman 
Baldwin AH, Simpson TW, Weammert SE (2009) Urban wet ponds and wetlands best management practice. Final Report, the Chesapeake Bay Program, MD

Belmont MA, Metcalfe CD (2003) Feasibility of using ornamental plants (Zantedeschia aethiopica) in subsurface flow treatment wetlands to remove nitrogen, chemical oxygen demand and nonylphenol ethoxylate surfactants a laboratory-scale study. Ecol Eng 21:233-247

Beutel MW (2006) Inhibition of ammonia release from anoxic profundal sediments in lakes using hypolimnetic oxygenation. Ecol Eng 28(3):271-279

Billore SK, Prashant EM, Sharma JK (2008) Restoration and conservation of stagnant water bodies by gravel-bed treatment wetlands and artificial floating reed beds in tropical India. In: Sengupta M, Dalwani R (eds) Proceedings of the 12th World Lake Conference, pp 981-987

Bold and Gold ${ }^{\mathrm{TM}}$ : Filtration Media, Available at: http://www.sun treetech.com/files/Product\%20Brochure/brochure\%20pages\%20 BandG.pdf [Accessed 20 May 2011]

Breen PF (1990) A mass balance method for assessing the potential of artificial wetlands for wastewater treatment. Water Res 24: 689-697

Carpenter SR, Lodge DM (1986) Effects of submersed macrophytes on ecosystem processes. Aquat Bot 26:341-370

Chang NB, Wanielista M, O'Reilly A (2007) Use of alternative sorption media for removing nutrients associated with stormwater BMPs. Proceedings CD of ASCE/EWRI Annual Congress, Tampa

Chang NB, Hossain F, Wanielista M (2010) Filter media for nutrient removal in natural systems and built environments: I. previous trends and perspectives. Environ Eng Sci 27:689-706

Cui L, Ouyang Y, Lou Q, Yang F, Chen Y, Zhu W, Luo S (2010) Removal of nutrients from wastewater with Canna indica L. under different vertical-flow constructed wetland conditions. Ecol Eng 36:1083-1088

DeBusk TA, Peterson JE, Ramesh RK (1995) Use of aquatic and terrestrial plants for removing phosphorus from dairy wastewaters. Ecol Eng 5:371-390

Ewing K (1996) Tolerance of four wetland plant species to flooding and sediment deposition. Envir Expt Bot 36:131-146

Figge DAH, Hetrick BAD, Wilson GWT (1995) Role of expanded clay and porous ceramic amendments on plant establishment in mine spoils. Environ Pollut 88:161-165

Gabel B, Kozicki R, Lahl U, Podbielski A, Stachel B, Struss S (1982) Pollution of drinking water with nitrate. Chemosphere 11:11471154

Gersberg RM, Elkins BV, Lyon SR, Goldman CR (1986) Role of aquatic plants in wastewater treatment by artificial wetlands. Water Res 20:363-368

Govindarajan B (2008) Nitrogen dynamics in a constructed wetland receiving plant nursery runoff in southeastern United States. Dissertation, University of Florida, Gainesville

Greenway M, Polson C (2007) Macrophyte establishment in stormwater wetlands: coping with flash flooding and fluctuating water levels in the subtropics. Hydrology, Faculty of Environmental Sciences, Griffith University, Brisbane

Hammer DA (1989) Constructed wetlands for wastewater treatment: municipal, industrial, and agricultural. CRC Press, Boca Raton
Headley TR, Tanner CC, Council AR (2006) Application of floating wetlands for enhanced stormwater treatment: a review. NIWA Client Report, Auckland Regional Council, New Zealand

Hossain F, Chang NB, Wanielista M (2010) Modeling kinetics and isotherms of functionalized filter media for nutrient removal from stormwater dry ponds. Environ Prog Sustain Energy 29: 319-333

Huang CP, Wang HW, Chiu PC (1998) Nitrate reduction by metallic iron. Water Res 32(8):2257-2264

Iamchaturapatra J, Yi SW, Rhee JS (2007) Nutrient removals by 21 aquatic plants for vertical free surface-flow (VFS) constructed wetland. Ecol Eng 29:287-293

Kadlec RH, Knight RL (1996) Treatment Wetlands. CRC Press, Boca Raton

Kim-Shapiro DB, Gladwin MT, Patel RP, Hogg N (2005) The reaction between nitrite and hemoglobin: the role of nitrite in hemoglobin-mediated hypoxic vasodilation. J Inorg Biochem 99(1):237-246

Mickle AM, Wetzel RG (1978a) Effectiveness of submersed angiosperm-epiphyte complexes on exchange of nutrients and organic carbon in littoral systems. I. Inorganic nutrients. Aquat Bot 4:303-316

Mickle AM, Wetzel RG (1978b) Effectiveness of submersed angiosperm-epiphyte complexes on exchange of nutrients and organic carbon in littoral systems. II. Dissolved organic carbon. Aquat Bot 4:317-329

Moshiri G (1993) Constructed wetlands for water quality improvement. Lewis Publishers, Boca Raton

Nahlik AM, Mitsch WJ (2006) Tropical treatment wetlands dominated by free-floating macrophytes for water quality improvement in Costa Rica. Ecol Eng 28:246-257

Pitt R, Maestre A, Morquecho R (2004) The National stormwater quality database (NSQD, Version 1.1). In: Proceedings of the 1st Annual Stormwater Management Research Symposium, pp 13-51

Sasser CE, Gosselink JG, Shaffer GP (1991) Distribution of nitrogen and phosphorus in a Louisiana freshwater floating marsh. Aquat Bot 41:317-331

Sawyer CN, McCarty PL, Parkin GF (2003) Chemistry for environmental engineering science. McGraw-Hill, New York

Servizi JA, Gordon RW (2005) Acute lethal toxicity of ammonia and suspended sediment mixtures to chinook salmon (Oncorhynchus tshawytscha). Bulletin Environ Contam Toxicol 44(4):650-656

Tarazona JV, Munoz MJ, Ortiz JA, Nunez MO, Camargo JA (2008) Fish mortality due to acute ammonia exposure. Aquac Res 18(2): $167-172$

Van der Valk AG, Davis CB, Baker JL, Beer CE (1979) Wetland functions and values, the state of our understanding. American Water Resources Association, Minneapolis, pp 457-467

Van Winkle SC, Pullman GS (2005) Achieving desired plant growth regulator levels in liquid plant tissue culture media that include activated carbon. Plant Cell Rep 24:201-208

Vymazal J (2007) Removal of nutrients in various types of constructed wetlands. Sci Total Environ 380:48-65

White SA, Seda B, Cousins M, Klaine SJ, Whitwell T (2009) Nutrient remediation using vegetated floating mats. SNA Research Conference 54:39-43

Xuan Z (2007) Nutrient and pathogen removal in a subsurface upflow wetland system using green sorption media. Masters 